\title{
Variable habitat use by Japanese eel affects dissemination of swimbladder parasite Anguillicola crassus
}

\author{
Yu San Han ${ }^{1,2, *}$, Ya Ting Chang ${ }^{2}$, Wann Nian Tzeng ${ }^{1,2}$ \\ ${ }^{1}$ Department of Life Science, and ${ }^{2}$ Institute of Fisheries Sciences, Science College of Life Science, National Taiwan University, \\ Taipei 106, Taiwan
}

\begin{abstract}
Freshwater habitat use by yellow-stage eels is facultative. Survival, infestation rates, and prevalence of the swimbladder parasite Anguillicola crassus (Nematoda) in European eel is higher in freshwater than in brackish water or seawater. This suggests that infestation patterns vary among habitats with different salinity. To evaluate whether Japanese eel Anguilla japonica populations with different habitat use behavior have different parasite dispersion modes, we examined by electron probe microanalyzer the otolith strontium:calcium ( $\mathrm{Sr}: \mathrm{Ca}$ ) ratios of 166 Japanese eels collected from the Kaoping River, southwestern Taiwan, in 2006 and 2007. According to the mean and SD of otolith Sr:Ca ratios, we differentiated between 3 types of habitat use in eels: freshwater, low-migratory (Type 1), brackish water, low-migratory (Type 2), and high-migratory (Type 3 ). The mean prevalence of A. crassus was lowest in Type 2, intermediate in Type 1, and highest in Type 3, but there were no significant differences. Mean intensity of $A$. crassus at the larval stage (but not adult stage) was significantly higher for Type 1 than for the other 2 types. Our results suggest that diverse habitat use by Japanese eels implies behavioral plasticity to make use of different ecological niches. High-migratory Type 3 eels, which dominate the population, may serve as vectors disseminating A. crassus among different habitats.
\end{abstract}

KEY WORDS: Otolith · Strontium:calcium (Sr:Ca) ratio · Anguillicola crassus · Infestation · Dissemination $\cdot$ Nematoda

\section{INTRODUCTION}

The Japanese eel Anguilla japonica Temminck \& Schlegel is a temperate catadromous fish showing a complex life cycle. Mature eels spawn in the western Mariana Islands, near 14 to $16^{\circ} \mathrm{N}, 142^{\circ} \mathrm{E}$ (Tsukamoto 1992, 2006). Hatched leptocephalus larvae drift from their spawning grounds with the North Equatorial Current (NEC) and then the Kuroshio Current (KC) for 4 to 6 mo, finally reaching the coasts of Northeast Asia (Cheng \& Tzeng 1996). There they metamorphose into glass eels along the continental shelf and disperse from the Philippines to Taiwan, mainland China, Korea, and north to Japan (Tesch 2003). After growing for many years, they start silvering at the onset of sexual maturity, and migrate back to their area of birth, where they spawn and die (Tzeng et al. 2000, Tesch 2003).
Japanese eel recruitment is in rapid decline, due to over-fishing, habitat destruction, and global climate changes (Tzeng 1985, 1986, Liao 2001, Dekker et al. 2003, Han et al. 2008a). The effective management of eel populations to ensure resource sustainability requires a thorough understanding of the life-history strategy of the Japanese eel. In recent years, otolith strontium:calcium (Sr:Ca) ratios have been used to trace the salinity life history of eels (Tzeng et al. 1997, Tsukamoto et al. 1998, Han et al. 2003a). The Japanese eel should be considered a facultative catadromous fish that can grow up in freshwater, brackish water, seawater, or migrate between freshwater and seawater (Tzeng et al. 1997, 2002, 2003, Tsukamoto et al. 1998, Tsukamoto \& Arai 2001). In estuarine habitats, salinity is highly variable. Eels choose a preferred salinity habitat in which to grow up (Han et al. 2003a). Eels showing low-migratory behavior 
are found in seawater, brackish water, or freshwater, whereas high-migratory eels may shift between these habitats. The migratory behavior of Japanese eel is well documented, its ecological implications, however, for both the host and its swimbladder parasite Anguillicola crassus are still poorly understood.

Anguillicola crassus, originally endemic in the Japanese eel in east Asia (Kuwahara et al. 1974, Nagasawa et al. 1994), was accidentally introduced into European waters in the early 1980s (Koops \& Hartmann 1989). It rapidly spread throughout Europe (Kirk 2003), North America (Fries et al. 1996, Barse et al. 2001), and north and east Africa (Sasal et al. 2008). Eels become infested by ingesting third-stage (L3) larvae preying either on copepods (Crustacea) (Kennedy \& Fitch 1990, Ooi et al. 1997) or on small fish (Kirk 2003) being intermediate, or paratenic hosts respectively, to the larvae. Adult $A$. crassus copulate in the lumen of the eels' swimbladder. Eggs or hatched second-stage (L2) larvae leave the swimbladder passively via the pneumatic duct, pass down the intestine, and are released into the water as motile L2 larvae (Kirk et al. 2000a,b). They attach to the substratum and undulate to stimulate predation by intermediate hosts. In their intermediate hosts they develop to infective L3 larvae, ready to infest eels as a definitive host (Thomas \& Ollevier 1993).

Salinity reduces egg-hatching, L2 larvae survival, and infestation rates of Anguillicola crassus significantly (Kirk et al. 2000a,b). Thus, it is reasonable to presume that both the prevalence and intensity in natural eel populations are low in habitats of high salinity (Taraschewski et al. 1987, Höglund et al. 1992, Pilcher \& Moore 1993). However, infested migrating eels may transport larvae and adult parasites among different habitats. For this reason, infestation patterns among ecologically different eel types could be modified to some extent. A. crassus infestation is abundantly studied for European eels; for Japanese eels, however, infestation ratios in relation to habitat salinity are poorly known. This study seeks to address this research gap.

Based on otolith Sr:Ca ratios we allocated specimens of Japanese eel to 3 types of habitat use behavior, and investigated the effect of this behavior on the infestation with Anguillicola crassus in order to better understand the role of habitat use on both the eel and its parasite.

\section{MATERIALS AND METHODS}

Sample collection. From June 2006 to July 2007, Japanese eels $(\mathrm{N}=166)$ were collected from the Kaoping River estuary, southwestern Taiwan. The sampling locations and the methods used for eel capture are described in detail by Han \& Tzeng (2006). The eels were trans- ported live to the laboratory and anesthetized with 500 ppm 2-phenoxyethanol dissolved in water. Length and weight of the individuals were measured to the nearest $1.0 \mathrm{~mm}$ and $0.1 \mathrm{~g}$, respectively. Only eels $>35 \mathrm{~cm}$, of a definitive gender, and with clear habitat use patterns were analyzed. They were decapitated for otolith collection and parasitological examination. The gender was determined by morphology (Han et al. 2003b).

Parasitological examination. Adult Anguillicola crassus were removed with forceps from the swimbladder and their species and numbers recorded (Han et al. 2008b). Swimbladder walls were checked for A. crassus larvae by squash preparation, using 2 Perspex plates. The prevalence, mean intensity of infestation, and abundance of the parasites were calculated according to Bush et al. (1997).

Otolith preparation and $\mathrm{Sr}$ :Ca ratio analysis. Sagittal otoliths, which are the largest of the 3 pairs, were prepared for Sr:Ca ratio analysis (Han et al. (2003a). Briefly, collected otoliths were stored in 95\% alcohol, air-dried, embedded in epofix resin, ground, and polished until the cores were exposed. The polished otoliths were coated with carbon in a high-vacuum evaporator. Sr and Ca concentrations (wt \%) were measured from the otolith primordium to its edge at $10 \mu \mathrm{m}$ intervals using an electron probe microanalyzer (EPMA; JEOL JXA-800M; settings: electron beam $5 \mu \mathrm{m}$ diameter, $15 \mathrm{kV}$ accelerating voltage, $5 \mathrm{nA}$ probe current).

Data analyses. Parasite prevalence among the 3 eel types was examined using the chi-square test (SPSS software, version 12.0). Differences in mean intensity of infestation among eel groups were analyzed with the non-parametric Kruskal-Wallis (K-W) test, followed by the Mann-Whitney $U$-test. Significance was accepted at $\alpha=0.05$.

\section{RESULTS}

\section{Otolith Sr:Ca ratio patterns}

Otoliths of 15 male and 151 female Japanese eels were examined for Sr:Ca ratio (Table 1). At a distance between 100 and $200 \mu \mathrm{m}$ from the otolith primordium, which corresponds to the marine leptocephalus stage, the $\mathrm{Sr}$ :Ca ratios dropped markedly and independently from habitat use. Based on the SD of the mean $\mathrm{Sr}: \mathrm{Ca}$ ratio at a distance $>200 \mu \mathrm{m}$ from the primordium, each eel was allocated to either a low-migratory or high-migratory subgroup. The higher the SD value of the Sr:Ca ratio, the more migratory the behavior of the individual was considered.

The $1.4 \%$ value of SD of the Sr:Ca ratio was used to discriminate low-migratory eels (Type 1 and 2) from high-migratxory ones (Type 3) (Table 1; Fig. 1). For 
Table 1. Anguilla japonica infested by Anguillicola crassus. Japanese eels from the Kaoping River, 3 migratory types: (1) freshwater, low-migratory; (2) brackish water, low-migratory; (3) high-migratory. N: Sample size; TL: mean total length \pm SD; BW: mean body weight \pm SD. Parasitic Anguillicola crassus from the eels' swimmbladder: Prev.: prevalence; Abund.: abundance.

$\mathrm{L}$ : mean number of larvae $\pm \mathrm{SD} ; \mathrm{A}$ : mean number of adults $\pm \mathrm{SD} ; \mathrm{L}+\mathrm{A}$ : total of larvae plus adults $\pm \mathrm{SD}$

\begin{tabular}{|c|c|c|c|c|c|c|c|c|c|}
\hline \multirow{2}{*}{$\begin{array}{l}\text { Migratory } \\
\text { type }\end{array}$} & \multirow[t]{2}{*}{$\mathrm{N}$} & \multirow{2}{*}{$\begin{array}{c}\text { Ratio } \\
\text { Male:Female }\end{array}$} & \multirow{2}{*}{$\begin{array}{c}\mathrm{TL} \\
(\mathrm{mm})\end{array}$} & \multirow{2}{*}{$\begin{array}{l}\text { BW } \\
(g)\end{array}$} & \multirow{2}{*}{$\begin{array}{c}\text { Prev. } \\
(\%)\end{array}$} & \multirow[t]{2}{*}{ Abund. } & \multicolumn{3}{|c|}{ - Mean intensity } \\
\hline & & & & & & & L & A & $\mathrm{L}+\mathrm{A}$ \\
\hline 1 & 39 & $4: 35$ & $482.6 \pm 140.0$ & $170.0 \pm 223.9$ & 41.0 & 1.0 & $8.0 \pm 10.4$ & $1.2 \pm 0.6$ & $2.5 \pm 4.7$ \\
\hline 2 & 32 & $3: 29$ & $452.3 \pm 67.0$ & $108.3 \pm 65.3$ & 28.1 & 0.5 & $1.0 \pm 0.0$ & $1.6 \pm 0.5$ & $1.7 \pm 0.7$ \\
\hline 3 & 95 & $8: 87$ & $479.3 \pm 84.8$ & $141.3 \pm 96.5$ & 46.3 & 0.8 & $2.0 \pm 1.7$ & $1.6 \pm 0.7$ & $1.6 \pm 0.9$ \\
\hline
\end{tabular}
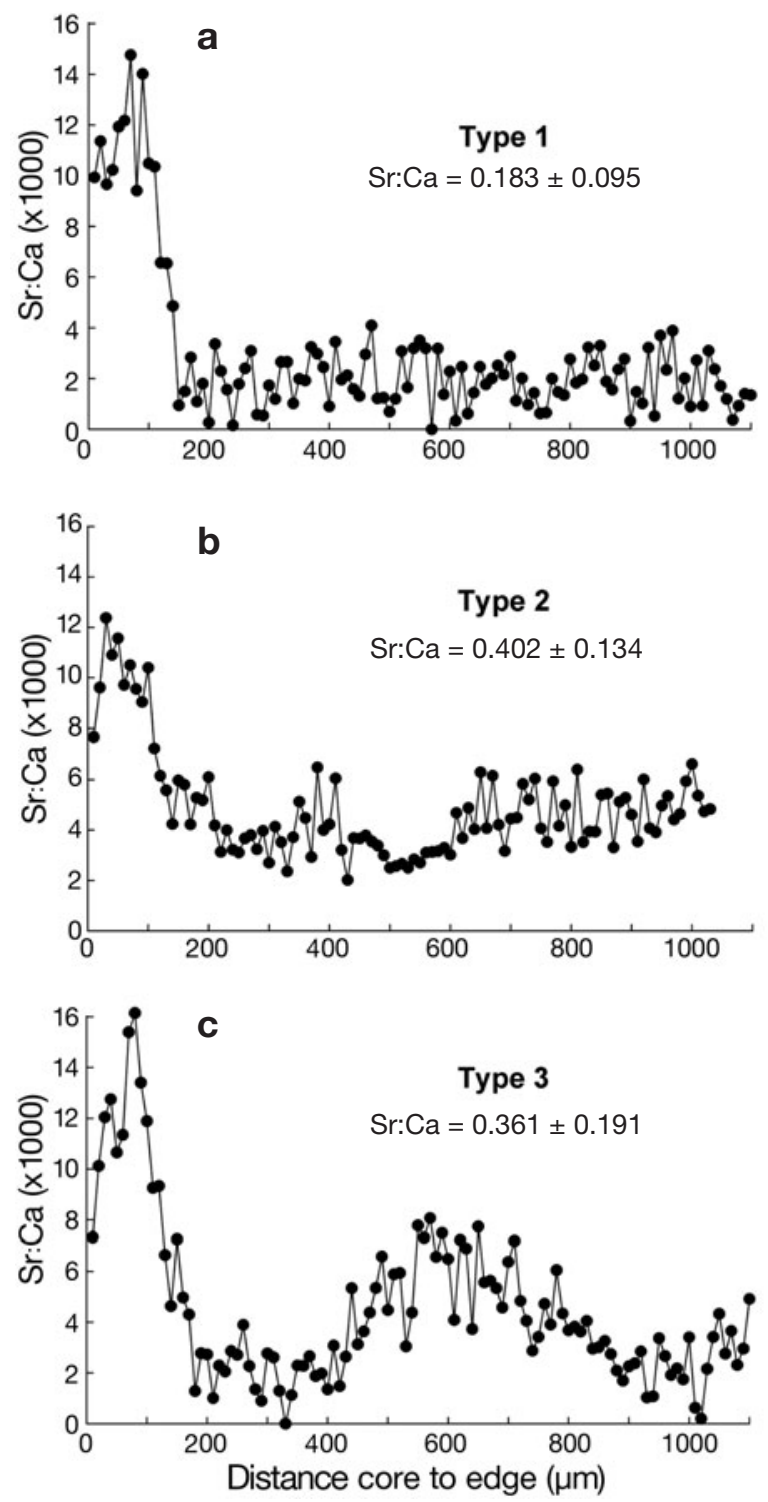

Fig. 1. Anguilla japonica. Temporal changes in otolith $\mathrm{Sr}: \mathrm{Ca}$ ratios in 3 different migratory types of Japanes eel from the estuary of the Kaoping River. Ratio maxima around a distance of $100 \mu \mathrm{m}$ belong to the otolith primordium (marine leptocephalus stage of eel larvae). Only ratios from a distance $>200 \mu \mathrm{m}$ were used to compute the mean and SD (in graphs). Type 1: low-migratory, freshwater; (b) Type 2: low-migratory, brackish water; (c) Type 3: high migratory samples caught from freshwater and estuary habitats, mean otolith Sr:Ca ratios are 2.2 and $3.1 \%$ respectively (Tzeng et al. 2002). In the present study we set a mean $\mathrm{Sr}$ :Ca ratio of $2.4 \%$ as a boundary to separate low migratory freshwater eels from low migratory brackish water ones (Type 1 or 2, respectively) (Table 1; Fig. 1).

Tzeng et al. (2002) used a mean $\mathrm{Sr}$ :Ca ratio of $4 \%$ to discriminate the freshwater from seawater eel; however, since very few seawater-type eels were caught in the Kaoping River estuary (Tzeng et al. 2002: $<5 \%$; this study), these eels were thus incorporated into either Type 2 or 3, based on this study's classification method.

\section{Parasitological data}

All parasites found in the swimbladders were Anguillicola crassus, identified after Han et al. (2008b). The prevalence of adult $A$. crassus was lowest in Type 2 $(28.1 \%)$, intermediate in Type $1(41.0 \%)$, and highest in Type $3(46.3 \%)$ eels. Nonetheless, no significant differences were observed $\left(\chi^{2}=3.27\right.$, df $\left.=2, p=0.20\right)$ (Table 1). The mean intensity of larval A. crassus differed significantly in the 3 eel types (K-W test, $\mathrm{p}<0.01$ ). Statistical significance was found between Type 1 and 2 $(p=0.02)$ and 1 and $3(p<0.01)$, but not between Type 2 and $3(\mathrm{p}=0.23)$. The mean Intensity of adult $A$. crassus did not differ significantly among the 3 eel types (K-W test, $\mathrm{p}=0.17)$. The mean intensity of total $A$. crassus (larvae + adults) differed significantly among the 3 eel types (K-W test, $\mathrm{p}<0.01)$, with significance occurring between Type 1 and $2(p=0.02)$ and 1 and $3(p<0.01)$, but not between Type 2 and $3(p=0.91)$.

\section{DISCUSSION}

In the European eel, both the prevalence and intensity of infestation of Anguillicola crassus are generally lower in seawater than in freshwater (Taraschewski et al. 1987, Höglund et al. 1992, Pilcher \& Moore 1993). L2 larvae can survive up to $100 \mathrm{~d}$ in freshwater, $70 \mathrm{~d}$ in $50 \%$ seawater (17 psu), and $40 \mathrm{~d}$ in seawater (33 psu) Kirk et al. (2000a); the length of time they are infec- 
tions to intermediate or paratenic hosts decreases with increased salinity: up to $80 \mathrm{~d}$ in freshwater, $21 \mathrm{~d}$ in 17 psu seawater, and $8 \mathrm{~d}$ in 33 psu seawater at $15^{\circ} \mathrm{C}$. The short lifespan of $A$. crassus larvae in saline water is likely the cause of lower infestation in those habitats. In this study, the prevalence of $A$. crassus was lower in brackish water than in freshwater, and the migratory Type 3 eels that dominate the population suffer a higher parasite prevalence, although, no significant differences were observed among the 3 eel types. We believe that migratory eels encounter more diverse habitats and thus face a greater chance of becoming infested. Highly migratory eels may also serve as vectors, disseminating $A$. crassus among habitats, thus efficiently buffering the different infestive potentials among microhabitats with different salinity levels. Since all our eel samples came from an estuarine area, higher or lower infestation rates in eels from upstream (freshwater) or downstream (more saline) habitats cannot be excluded. The Kaoping River is small and lacks stable freshwater input throughout the year, and there are many weirs along the river that block the upstream migration of eels. Thus, only few eels can be caught in the middle and upper reaches of the Kaoping River (Han \& Tzeng 2007). Accordingly, different habitat-use strategies among eels may, in theory, disperse parasite infestation risk. However, the migratory behavior of Type 3 eels seems to counteract the seawater barrier and thus may support the dissemination of $A$. crassus as the parasite may become dispersed by infested eels that migrate among separate rivers via coastal routes through saline waters. This would partially explain the quick dispersal of A. crassus from Germany to the whole of Europe within 10 yr (Kirk 2003).

The mean intensity of larval (but not adult) Anguillicola crassus was significantly higher in Type 1 eels than in Type 2 or 3 . This may reflect the longer lifespan and higher infestation rate of larval A. crassus in freshwater habitats. The comparable mean intensity for adult parasites, however, may be due to the regulatory mechanism of the eel host, which hinders most larvae from growing into adults. In contrast to its effects on European eels, A. crassus does not usually cause serious pathological damage in Japanese eels, as infestation tends to occur at low intensities (Egusa 1992, Würtz \& Taraschewski 2000, Kirk 2003, Taraschewski 2006, Han et al. 2008b). Laboratory infestation experiments reveal Japanese eels to be more resistant (Knopf \& Mahnke 2004) and to show stronger humoral immune response (Nielsen 1999) to A. crassus than European eels. Thus, although the mean intensity of larval infestation in freshwater habitats is high, its significance would disappear within a relatively short time, because only a few larvae will survive to adults in the Japanese eels.
In conclusion, life-history scans of otolith $\mathrm{Sr}$ :Ca ratios have confirmed that yellow-stage Japanese eels occupy freshwater and brackish water, with some eels migrating between the 2 habitats. The diverse habitat uses of Japanese eels suggest a behavioral plasticity that helps eels maximize their range of habitat possibilities. However, the parasite Anguillicola crassus seems to benefit from the dominant migratory Type 3 eels, which may serve as vectors in disseminating parasites among habitats of diverse salinity regimes.

Acknowledgements. This study was financially supported by the National Science Council of the Republic of China (NSC 95-2313-B-002-019 and NSC 96-2313-B-002-008). The authors are grateful to all previous students and research assistants for their help in field and laboratory work.

\section{LITERATURE CITED}

Barse AM, Scott AM, Melissa AV, Laura EE, Julie AW (2001) The swimmbladder nematode Anguillicola crassus in American eels (Anguilla rostrata) from middle and upper regions of Chesapeake Bay. J Parasitol 87:1366-1370

Bush AO, Lafferty KD, Lotz JM, Shostak AW (1997) Parasitology meets ecology on its own terms: Margolis et al. revisited. J Parasitol 83:575-583

> Cheng PW, Tzeng WN (1996) Timing of metamorphosis and estuarine arrival across the dispersal range of the Japanese eel Anguilla japonica. Mar Ecol Prog Ser 131:87-96

Dekker W, Casselman JM, Cairns DK, Tsukamoto K, Jellyman D, Lickers H (2003) Worldwide decline of eel resources necessitates immediate action: Québec declaration of concern. Fisheries 28:28-30

Egusa S (1992) Nematode diseases. In: Egusa S (ed) Infectious diseases of fish. A.A. Balkema, Rotterdam, Brookfield, p 643-657

Fries LT, Williams DJ, Johnson SK (1996) Occurrence of Anguillicola crassus, an exotic parasite swim bladder nematode of eels, in the southeastern United States. Trans Am Fish Soc 125:794-797

Han YS, Tzeng WN (2006) Sex ratio as a means of resource assessment for the Japanese eel Anguilla japonica: a case study in the Kaoping River of Taiwan. Zool Stud 45: $255-263$

> Han YS, Tzeng WN (2007) Sex-dependent habitat use by the Japanese eel Anguilla japonica in Taiwan. Mar Ecol Prog Ser 338:193-198

Han YS, Yu JYL, Liao IC, Tzeng WN (2003a) Salinity preference of the silvering Japanese eel Anguilla japonica: evidences from the pituitary prolactin mRNA levels and otolith Sr:Ca ratios. Mar Ecol Prog Ser 259:253-261

> Han YS, Liao IC, Huang YS, He JT, Chang CW, Tzeng WN (2003b) Synchronous changes of morphology and gonadal development of silvering Japanese eel Anguilla japonica. Aquaculture 219:783-796

> Han YS, Sun YL, Liao YF, Shen KN, Liao IC, Tzeng WN (2008a) Temporal analysis of population genetic composition in the overexploited Japanese eel Anguilla japonica. Mar Biol 155:613-621

Han YS, Chang YT, Taraschewski FH, Chang SL, Chen CC, Tzeng WN (2008b) The swimbladder parasite Anguillicola crassus in native Japanese eels and exotic American eels 
in Taiwan. Zool Stud 47:667-675

Höglund J, Andersson J, Härdig J (1992) Haematological responses to the European eel, Anguilla anguilla L., to sublethal infestation by Anguillicola crassus in a thermal effluent of the Swedish Baltic. J Fish Dis 15:507-514

Kennedy CR, Fitch DJ (1990) Colonization, larval survival and epidemiology of the nematode Anguillicola crassus, parasitic in the eel, Anguilla anguilla, in Britain. J Fish Biol 36:117-131

Kirk RS (2003) The impact of Anguillicola crassus on European eel. Fish Manag Ecol 10:385-394

Kirk RS, Lewis JW, Kennedy CR (2000a) Survival and transmission of Anguillicola crassus Kuwahara, Niimi and Itagaki, 1974 (Nematoda) in seawater eels. Parasitology 120: 289-295

Kirk RS, Kennedy CR, Lewis JW (2000b) Effect of salinity on hatching, survival and infectivity of Anguillicola crassus (Nematoda: Dracunculoidea) larvae. Dis Aquat Org 40: 211-218

Knopf K, Mahnke M (2004) Differences in susceptibility of the European eel (Anguilla anguilla) and the Japanese eel (Anguilla japonica) to the swim-bladder nematode Anguillicola crassus. Parasitology 129:491-496

Koops H, Hartmann F (1989) Anguillicola-infestations in Germany and in German eel imports. J Appl Ichthyology 5: 41-45

Kuwahara A, Niimi A, Itagaki H (1974) Studies on a nematode parasitic in the air bladder of the eel. I. Description of Anguillicola crassus n. sp. (Philometridea, Anguillicolidae). Jpn J Parasitol 23:275-279

Liao IC (2001) A general review on aquaculture in Asia: a focus on anguillid eel. In: Liao IC (ed) Keynote Addresses, The 5th and 6th Asian Fisheries Forums. AFS Special Publication No. 11, p 39-54

Nagasawa K, Kim YG, Hirose H (1994) Anguillicola crassus and A. globiceps (Nematoda: Dracunculoidea) parasitic in the swimbladder of eels (Anguilla japonica and A. anguilla) in East Asia: a review. Folia Parasitol 41:127-137

Nielsen ME (1999) An enhanced humoral immune response against the swimbladder nematode, Anguillicola crassus, in the Japanese eel, Anguilla japonica, compared with the European eel, A. anguilla. J Helminthol 73:227-232

Ooi HK, Lin CC, Chen MC, Wang WS (1997) Eucyclops euacanthus (Copepoda: Cyclopidae) is an intermediate host of Anguillicola crassus (Nematoda: Dracunculoidea) in Taiwan. Taiwan J Vet Med Anim Husb 67:135-138

Pilcher MW, Moore JF (1993) Distribution and prevalence of Anguillicola crassus in eels from the tidal Thames catchment. J Fish Biol 43:339-344

Sasal P, Taraschewski H, Valade P, Grondin H, Wielgoss S, Moravec F (2008) Parasite communities in eels of the

Editorial responsibility: Hans Heinrich Janssen,

Oldendorf/Luhe, Germany
Island of Reunion (Indian Ocean): a lesson in parasite introduction. Parasitol Res 102:1343-1350

Taraschewski H (2006) Hosts and parasites as aliens. J Helminthol 80:99-128

- Taraschewski H, Moravec F, Lamah T, Anders K (1987) Distribution and morphology of two helminthes recently introduced into European eel populations: Anguillicola crassus (Nematoda, Drancunculoidea) and Paratenuisentis ambiguus (Acanthocephala, Tenuisentidae). Dis Aquat Org 3:167-176

Tesch FW (2003) The eel. Blackwell Science, Oxford, UK

Thomas K, Ollevier F (1993) Hatching, survival and penetration efficiency of second-stage larvae of Anguillicola crassus (Nematoda). Parasitology 107:211-217

Tsukamoto K (1992) Discovery of the spawning area for Japanese eel. Nature 356:789-791

Tsukamoto K (2006) Spawning of eels near a seamount: tiny transparent larvae of the Japanese eel collected in the open ocean reveal a strategic spawning site. Nature 493: 929

Tsukamoto K, Arai T (2001) Facultative catadromy of the eel Anguilla japonica between freshwater and seawater habitats. Mar Ecol Prog Ser 220:265-276

Tsukamoto K, Nak I, Tesch WV (1998) Do all fresh water eels migrate? Nature 396:635-636

Tzeng WN (1985) Immigration timing and activity rhythms of the eel, Anguilla japonica, elvers in the estuary of northern Taiwan, with emphasis on environmental influences. Bull Jpn Soc Fish Oceanogr 47/48:11-28

Tzeng WN (1986) Resources and ecology of the Japanese eel Anguilla japonica elvers in the coastal waters of Taiwan. China Fish Monthly 404:19-24

Tzeng WN, Severin KP, Wickström H (1997) Use of otolith microchemistry to investigate the environmental history of European eel Anguilla anguilla. Mar Ecol Prog Ser 149: $73-81$

Tzeng WN, Lin HR, Wang CH, Xu SN (2000) Differences in size and growth rates of male and female migrating Japanese eels in Pearl River, China. J Fish Biol 57: 1245-1253

> Tzeng WN, Shiao JC, lizuka Y (2002) Use of otolith Sr:Ca ratios to study the riverine migratory behaviors of Japanese eel Anguilla japonica. Mar Ecol Prog Ser 245:213-221

Tzeng WN, Iizuka Y, Shiao JC, Yamada Y, Oka H (2003) Identification and growth rates comparison of divergent migratory contingents of Japanese eel (Anguilla japonica). Aquaculture 216:77-86

> Würtz J, Taraschewski H (2000) Histopathological changes in the swimbladder wall of the European eel Anguilla anguilla due to infection with Anguillicola crassus. Dis Aquat Org 39:121-134

Submitted: September 24, 2008; Accepted: January 19, 2009 Proofs received from author(s): March 12, 2009 